\title{
REFLEKSI HERMENEUTIKA DALAM STUDI ISLAM
}

\author{
Eko Nopriyansa, Rama Wijaya Kesuma Wardani \\ STAI Bumi Silampari Lubuklinggau, Indonesia \\ ekonopriyansyah@gmail.com,aldiscooter7@gmail.com
}

\begin{tabular}{ll}
\hline & Abstrak \\
\hline Article History & The purpose of this literature analysis \\
Received : 05-10-2020 & is to find out the reflection of \\
Revised : 10-12-2020 & hermeneutics in Islamic scientific \\
Accepted : 14-12-2020 & studies, in this effort the method used is \\
\hline Keywords: & qualitative descriptive, namely the \\
Refleksi & study of the literature literature by \\
Hermeneutika & comprehensively explaining the \\
Studi Islam & fundamental problems that become the \\
& object of study in research, so that in \\
& this study the results of the analysis are \\
& found. shows that hermeneutics in \\
& Islamic studies can be considered, \\
& although it requires analysis and \\
& improvement of several aspects of \\
methodology and related problems that \\
are indicated to create a crucial \\
scientific nuance.
\end{tabular}

\section{Pendahuluan}

Kehadiran dan perkembangan hermeneutika dalam studi keislaman, tidak lepas dari rangkaian sejarah tokoh dan pemikir Kristen dalam tradisi keilmuannya untuk menginterprestasi kitab Bibel, yang kemudian mengalami pergeseran menjadi suatu metode dalam menafsirkan teks-teks secara umum. Senada dengan itu Wahidatul Wafa dalam tulisannya mengungkapkan bahwah perkembangan hermeneutika terhitung sejak abad ke 16, pada saat itu hermeneutika lebih ditekankan pada prioritas untuk membantu para teolog Kristen dalam memahami teks-teks yang dianggap sulit dari teks Bibel dan juga untuk menentukan semacam pemahaman yang benar dari sekian banyaknya penafsiran yang mungkin dilakukan. Hingga dalam rangkaiannya model hermeneutika ini berkembang lebih luas, yang tidak hanya terbatas pada upaya untuk memberikan interpretasi kepada teks bibel saja, namun dibuka secara luas untuk 
memahami teks-teks secara umum, hingga seperti yang kita kenal saat ini (Wahidatul Wafa: 2017).

Jika kita menganalisa secara komprehensif menunjukan bahwah rangkaian sejarah dalam perkembangan Hermeneutika dalam kajian Islam, menunjukan bahwah kajian hermeneutika telah mengundang beberapa perdebatan hangat dikalangan tokoh-tokoh Islam, mekipun tidak dapat di elakan banyak juga diantara tokoh-tokoh Islam yang notabenenya mendukung dan menerima konsep hermeneutika dengan batasan dan prinsip-prinsip yang cukup ketat. Beberapa pemikir seperti Nasir Hamid, memiliki catatan penting dalam kiprah akademiknya terhadap hermeneutika dalam studi Islam (Nurkhalis: 2015). Dalam ulasan ini, penulis berupaya melakukan kajian literature terhadap refleksii hermeneutika dalam studi keislaman baik berdasarkan kajian buku, jurnal ilmiah, materi kuliah, hingga analisis terhadap kurikulum Hermeneutika Agama pada beberapa perguruan tinggi di Indonesia, guna menemukan berbagai perspektif dalam mengulas tentang kehadiran hermeneutika dalam studi keislaman hingga memuat beberapa kritik maupun hasil analisis yang lebih komprehensif terhadap posisi hermeneutika dalam studi Islam.

\section{Metode Penelitian}

Berdasarkan jenisnya Karya tulis ini merupakan kajian pustaka atau Library Reseach, dalam kerangka akademik seperti Prasetya irawan menjelaskan bahwah, Library Reseach ini merupakan penelitian yang menandaskan kepada hasil tinjauan kepustakaan dengan menela'ah sumber-sumber tertulis yang memiliki relevansi dengan ojek kajian atau penelitian. (Prasetya Irawan: 1999).

\section{Pembahasan}

Dari beberapa tinjauan dan tela'ah terhadap tulisan-tulisan sebelumnya, menunjukan bahwah perkembangan hermeneutica dalam Islam, tidak lepas dari peranan penting para pelopor dan cendikiawan muslim di era kontemporer. Beberapa cendikiawan muslim yang cukup populer dan diperhitungkan dalam pemikiran Islam seperti Fazlur Rahman, merupakan salah satu tokoh yang cukup dikenal dan mendominasi dalam kajian hermeneutica. Lebih jauh Sucipto mengungkapkan bahwah secara keseluruhan karya-karya Fazlur Rahman merupakan sebuah upaya untuk menyingkapi kandungan isi Al-qur'an. Dalam upaya menafsirkan Al-Qur'an inilah nampaknya 
Fazlur Rahman mulai menggulirkan konsep dan pemikirannya yang berupaya memberikan pembedahan terhadap sunnah dan hadits dan membatasinya secara transparan antara yang ideal moral dengan yang murni sebagai hukum al-Qur'an. Oleh karna itu, dalam upaya merealisasikan pemikirannya ini, Rahman banyak memformulasikan antara metodologi tafsir al-Qur'an dengan model gerakan ganda sebagai bentuk aplikasinya yaitu merekontruksi dua kelompok Islam antara Tradisionalis dan Modern (Sucipto: 2020).

Selain Fazlur Rahman, sosok tokoh Islam kontemporer seperti Arkoun, juga cenderung mengatakan bahwah al-Qur'an merupakan produk sejarah, dan perlu sebuah upaya penafsiran ulang terhadap alqur'an. Trem ini nampaknya telah menambah warna dalam sejarah pemikiran Islam pada konteks perkembangan hermeneutika dalam bidang studi Islam. Ishak Hariyanto menuturkan, bahwah Tesis Arkoun yang mengusung Islamologi terapan, yang berupaya mengkritik Islamologi klasik yang diklaim tidak dapat menguniversalkan pemikiran Islam kedalam ruang lingkup yang lebih luas menjadi titik muara diskursus dalam studi Islam terhadap hermeneutic ala arkoun ini dari beberapa kalangan islam lainnya (Ishak Heriyanto: 2018). Dari dua ulasan tersebut menunjukan bahwah beberapa tokoh-tokoh Islam kontemporer tersebut secara keilmuan menjadi titik nadi perdebatan dan diskusi tentang posisi hermeneutika dalam studi keislaman. Dalam perkembangnnya hingga saat ini, hermeneutika terus menjadi perbincangan dan mengundang diskusi maupun perdebatan dikalangan tokoh-tokoh Islam terhadap refleksi Hermeneutika terhadap beberapa studi Islam, seperti studi Tafsir, Fiqih, Hadits dan beberapa studi keislaman lainnya.

Konsep pemikiran dan metode hermeneutika yang dipahami sebagai alat untuk menafsirkan teks Al-qur'an sebagai kitab suci umat Islam ini, nampakya menjadi kajian menarik dalam perbincangan internal Islam, dikarenakana dalam beberapa catatan menunjukan bahwah disamping derasnya semangat bagi kelompok yang bersikaf terbuka untuk menerima hermeneutika juga pada sisi tertentu ada kelompok yang meragukan dan mempertanyakan eksistensi hermeneutika yang kerap diposisikan sebagai metode tafsir terhadap Al-qur'an. Sebelum kita lebih jauh menyoroti potret hermeneutic dalam studi tafsir Al-qur'an, beberapa analisis Lukmanul Hakim dalam tulisannya, mengungkapkan bahwah ditinjau dari fungsiya, 
Hermeneutika secara umum berfungsi untuk membantu mendiskusikan teks, mempermudah menjelaskan teks, hingga memberi arahan terkait masalah hukum (Lukmanul Hakim: 2016).

Mudhofir Abdullah dalam tulisannya Kesejarahan al-Qur'an dan Hermeneutika, menyatakan bahwah secara keilmuan, titik muara dari upaya menafsirkan Al-qur'an dengan metode hermeneutika dimulai sejak ulama-ulama khalaf hingga kontemporer seperti Hasan hanafi, Muhammad Taha, Nasir Hamid Abu Zaid dan Fazlur Rahman, yang telah berupaya dengan baik memanfaatkan teori-teori kontemporer dengan pendekatan hermeneutika. Lebih jauh, secara runtut Adullah berasumsi bahwah meski pada awalnya hermeneutika ini kerap ditolak oleh kelompok ulama konservatif karena dianggap tidak cocok dengan keyakinan bahwa hermeneutika adalah tradisi keilmuan Kristen, namun secara perlahan ilmu ini telah diterima sebagai suatu keniscayaan. Jika hermeneutika digunakan sebagai alat bantu analisis al-qur'an secara benar, maka akan menghasilkan suatu khazanah makna (Mudhofir Abdulah, 2014: 77). Dalam tulisan ini, Mudhofir dengan beberapa analisisnya memeposisikan diri dengan pendekatan persetujuan terhadap penerapan hermeneutika terhadap penafsiran al-qur'an, dari beberapa analisis yang lebih sfesifik, Madhofir meyakini bahwah Al-Qur'an adalah wahyu Allah yang ditujukan untuk kemaslahatan manusia dan alam, sehingga ia harus dipahami dari sudut logika manusia. Ia, tentu saja, bukan kitab yang eksklusif yang hanya milik seseorang atau kelompok orang dan dengannya mereka menentukan standar moral untuk semua. Pendekatan hermeneutika, dapat memperkaya kapasitas makna teks dan bahkan memperkaya moral makna teks. Pendekatan ini dianggap sangat efektif untuk menemukan ayat-ayat yang nampak destruktif bagi nilai moral dan sebagai gantinya dipilih makna yang menghadirkan kemaslahatan manusia dan alam semesta.

Bertolak dengan pemikiran dan hasil analisis sebelumnya, Muzayin mengungkapkan, bahwah kehadiran Hermeneutika dalam perkembangannya, melahirkan berbagai diskursus baru dalam studi Islam. Terlebih, hermeneutika ini merupakan tradisi keilmuan Kristen, yang pada mulanya dipakai untuk memberikan interprestasi terhadap kitab Bibel (Muzayin, 2015: 112). Bebarapa argumentasi dan alasan prinsip terhadap sikaf keraguannya terhadap hermeneutika juga sekaligus mengkritik kelompok yang notbenenya menolak secara totalitas hermeneutika. Berdasarkan pendekatannya, nampaknya 
Muzayin lebih sejalan dengan pemikiran Qurais Shihab yang mengklaim memposisikan diri pada poros pertengahan. Dalam penyederhanaan analisisnya Muzayin berupaya menyampaikan beberapa tokoh dan pemikirannya terhadap hermenetika diantaranya pihak yang kontra adalah Muhammad Mahmud Kalu dan Adian Husaini, Mereka menegaskan penolakannya dengan alasan bahwa hermeneutika merupakan terminologi Barat yang awalnya digunakan untuk menafsirkan Bibel (Muzayin, 2015: 113).

Beberapa makalah mahasiswa pasca sarjana, seperti yang di ulas oleh Muhammad Anshor dengan menandaskan pemikiran Farid Esack, dalam tema khusus menampilkan sketsa dan konteks perkembangan hermeneutika dalam studi Islam yang meliputi era kontemporer yang dimulai dan didominasi oleh hasan hanafi beserta beberapa tokoh Islam lainnya, sekaligus menampilkan perkembangan secara praktis penggunaan hermeneutika oleh ulama ulama klasik (Muhammad Asror: 2020). Beberapa bukti bahwah dalam perkembangannya sejak awal hermeneutika secara praktik sudah digunakan dalam menafsirkan Al-qur'an, adalah bisa dilihat perkembangan studi al-qur'an dengan tampilnya beberapa metode seperti Asbabun Nuzul, adanya perbedaan dalam komentar actual tentang Al-qur'an, hingga adanya kategori dalam penafsiran tradisional seperti kategori tafsir Syi'ah, Mu'tazila, tafsir hukum, tafsir filsafat dan lain sebagainya (Muhammad Asror: 2020). Dari beberapa pendekatan sebelumnya menunjukan bahwah dalam perkembangannya, perdebatan dan pro kontra terhadap kehadiran hermeneutika dan kegunaannya dalam penafsiran Al-qur'an, masih berlangsung hingga saat ini.

1.1. Tabel Beberapa Tokoh Hermeneutika dan Pemikirannya Dalam Studi Al-qur'an

\begin{tabular}{|c|l|l|l|}
\hline No & Tokoh Hermeneutic & \multicolumn{1}{|c|}{ Konsep Pemikiran } & $\begin{array}{c}\text { Implikasi Terhadap } \\
\text { Al-qur'an }\end{array}$ \\
\hline 1 & Fazlur Rahman & $\begin{array}{l}\text { Merekontruksi penafsiran } \\
\text { Qur'an dengan mengedepankan } \\
\text { konteks histori dan sosial moral } \\
\text { yang relevan (Ulya: 2020). }\end{array}$ & $\begin{array}{l}\text { menafsirkan ayat-ayat } \\
\text { bernuansa hukum dengan } \\
\text { berpayung rumusan } \\
\text { hermeneutika, dikedepankan } \\
\text { bukan berhenti pada perolehan } \\
\text { kepastian hukum sebuah } \\
\text { masalah yang terkandung dalam } \\
\text { ayat, tetapi justru pada tujuan } \\
\text { moral sosial umum yang } \\
\text { ditonjolkan dari pemahaman } \\
\text { ayat tersebut (Ulya: 2020). }\end{array}$ \\
\hline
\end{tabular}




\begin{tabular}{|c|c|c|}
\hline M. Arkoun & 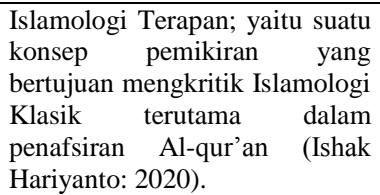 & $\begin{array}{l}\text { Membuka ruang bagi teks al- } \\
\text { Qur'an sebagai suatu yang } \\
\text { bebas untuk di interpretasi } \\
\text { (Ishak Hariyanto: 2020). }\end{array}$ \\
\hline Sayyed Husaen Nasr & $\begin{array}{l}\text { Konsep Tradisoal dengan } \\
\text { prinsip bahwah Al-qur'an yang } \\
\text { turun dari langit disertai dengan } \\
\text { manifestasi ilahi (wahyu) yang } \\
\text { disusaikan dengan konteks } \\
\text { masyarakat yang berbeda-beda } \\
\text { (Luluk Khumaerah,2019:4). }\end{array}$ & $\begin{array}{l}\text { Pemahaman terhadap Al-qur'an } \\
\text { hanya bisa di pahami melalui } \\
\text { tafsiran mufasir klasik } \\
\text { (Luluk Khumaerah,2019:4). }\end{array}$ \\
\hline Hasan Hanafi & $\begin{array}{l}\text { Hermeneutika Pembebasan atau } \\
\text { Teologi Pembebasan (Fadhli } \\
\text { Lukman: 2020). }\end{array}$ & \\
\hline
\end{tabular}

Safrudin dalam disertasinya Kontreversi Penerapan Hermeneutika dalam studi al-qur'an di Indonesia, menjelaskan bahwah secara garis besar penolakan hermeneutika menautkan kepada sebuah tujuan prinsip untuk mempertahankan tradisi keilmuan Islam (Safrudin Edi Wibowo, 2017: 398). Dalam menyoroti konteks kesejarahan kajian hermeneutika dalam studi keislaman di Indonesia, Safrudin menyuguhkan secara komprehensif beberapa rangkaian penolakan hermeneutika yang ditandai dengan diskursus yang terjadi antara tahun 2001 hingga 2004 dengan mencuatnya hermeneutika yang lebih terorganizir dan sistematis (Safrudin Edi Wibowo, 2017: 398). Oleh karna itu, dalam melihat konteks kesejarahan penolakan terhadap hermeneutika di Indonesia tidak lain berangkat dari kekuatiran terhadap fenomena pada saat itu seperti munculnya gerakan Islam Liberal dan masuknya hermeneutika dalam kurikulum pada pendidikan tinggi Islam.

Senada dengan itu, dapat dikatakan bahwah kehadiran hermeneutika dalam kurikulum pendidikan tinggi Keislaman di Indonesia, seperti jurusan teologi dan filsafat mendapat kritik dan respon serius dari kalangan Islam Konservatif (Ahmad Hifni, 2018: 3) Dalam melihat beberapa argumentasi kelompok yang melakukan penolakan terhadap hermeneutika, dikarenakan pada persoalan yang paling prinsip tak bisa di elakan bahwah pendukung atau komunitas yang pro terhadap hermeneutika, menetapkan suatu kebenaran yang dianggap relativ dan senantiasa bersikaf meragukan kebenaran secara subtantif, dimana dalam konsep Agama memiliki klaim Absolut. Setelah melihat secara umum gambaran trem pengelompokan beberapa respon Islam Indonesia terhadap kehadiran hermeneutika 
tersebut, penulis berkeyakinan pentingnya dalam tulisan ini untuk mengulas beberapa tokoh dan pemikiran tokoh-tokoh Islam Indonesia yang cukup keras menolak maupun mengkritik hermeneutika dalam studi keislaman terutama menyangkut penggunaan hermeneutika terhadap teks al-Qur'an.

Salah seorang cendikiawan yang kerap menyuguh pemikiran kritis dengan karya-karya menumental ialah Adian Husaini, beberapa karyanya seperti kontroversial penggunaan kata Allah dalam Agama Kristen, (Adian Husaini: 2015) Wajah Peradaban Barat dan beberapa karya sfesifiknya, menggambarkan posisi Adian cukup gesit sebagai tokoh yang tidak hanya bersikaf kritis, namun sangat selektif dan penuh kehati-hatian dalam melakukan studi pemikiran keislaman. Argo Victoria menggambarkan bahwah kritik Adian ini, tidak bisa lepas dari kekuatirannya terhadap indikasi perbedaan yang cukup mendasar antara tradisi keilmuan barat dan tradisi keilmuan keislaman. Pertama, bahwah Hermeneutika ini cenderung menghendaki sikap yang kritis dan bahkan cenderung curiga, kecenderungan memandang teks sebagai produk budaya hingga adanya sikaf mengabaikan masalah yang bersipat Ilahiyah serta aliran hermeneutika ini sangat plural, karenanya kebenaran tafsir ini menjadi sangat relative (Argo Victoria, 2017: 4-5). Kekutiran adian inii tergambarkan secara terang benderang pada beberapa pemikiran adian yang memiliki sikaf Kritis terhadap studi keilmuan dan pemikiran barat, yang masuk dan mempengaruhi corak keilmuan Islam dalam beberapa dekade.

Selain Adian Husaini, banyak diantara Tokoh kontemporer dan cendikiawan muslim seperti sosok Muhammad Imarah, termasuk tokoh cendikiawan yang cukup serius dalam memberikan kritik terhadap persoalan hermeneutika Nasir Hamid. Dalam penelitian mendalam dan analisa yang lebih serius, seperti upaya yang dilakukan Muhammad Zamri dalam Tesisnya studi kritis atas kritik Muhammad Imarah Terhadap Hermeneutika Nasir Hamid, (Muhammad Zamri: 2017) menunjukan bahwah Imarah berupaya mematahkan pandangan Nasir Hamid yang menyatakan bahwah al-qur'an adalah realitas budaya dan merupakan produk budaya. Beberapa landasan argument yang dimiliki Imarah adalah menandaskan kepada penafsiran alqur'an dengan al-qur'an itu sendiri (Muhammad Zamri: 2017). Dalam mencari beberapa relevansinya dengan gaya kritik Muhammad 
Imarah terhadap Hermeneutika, penulis berupaya melacak konsep pemikirannya seperti karyanya Islam dan Pluralitas, perbedaan dan kemajemukan dalam bingkai persatuan (Muhammad Imarah, 1999) Yang menunjukan bahwah sungguhpun Imarah cukup serius dalam mengkritik hermeneutika, namun ia cukup terbuka dan toleransi dalam keilmuan.

Dalam menyoroti kehadiran hermeneutika pada Islam global, penulis berupaya menyajikan beberapa relevansi kritik yang cukup popular dari beberapa cendikiawan muslim yang berupaya mengkritik penggunaan metode hermeneutika dalam studi Islam sekaligus menengahi terhadap perseberangan dengan pemikiran Islam Konservatif, terutama dalam penafsiran teks al-qur'an. Khaled M Abou Khaled, berbagai pemikirannya yang diajukan diyakini dapat menyatukan dua poros perbedaan yang tengah berlangsung dalam memperdebatkan posisi hermeneutika dalam Studi Islam. Alfi Qonita Badi'ati dalam tulisannya mengulas secara sfesifik terhadap konsep hermeneutic Khaled, yang pada prinsipnya memandang al-qur'an sebagai sebuah teks al-Quran tidaklah seperti teks biasa. Meskipun semua yang mampu menafsirkannya berhak untuk melakukan interpretasi, namun tidak dibenarkan reader otoritarianisme terhadap teks al-quran. Al-quran memiliki integritas tersendiri dibanding teks lain. Jika reader meninggalkan latar belakang lahirnya teks, dan membiarkan teks itu berbicara dalam bahasa dan symbol-nya saja, maka teks tersebut akan menjadi teks yang berdiri sendiri-tanpa pengarang. Hal ini menjadikan Khaled beralasan pentingnya meninggalkan otoritarisme teks, karena al-Quran sebagai fatwa keagamaan jika dibiarkan berbicara sendiri maka teks reader satusatunya pemegang otoritas Alfi (Qonita Badi'ati, 2016: 43). Dari ulasan ini menunjukan bahwah Khaled terlah berupaya menyelaraskan perdebatan terhadap pihak yang menolak maupun menerima hermeneutic dalam penafsiran al-qur'an. Pada sisi tertentu nampaknya Khaled berkeyakinan bahwah al-qur'an bersifat terbuka untuk ditafsir, namun sebagai kitab suci dan teks Khusus otoritas tertinggi tidak terletak pada subjek penafsir.

\section{Simpulan}

Dari uraian beberapa pokok permasalahan yang penulis paparkan sebelumnya dapat disimpulkan beberapa hasil analitis bahwah kehadiran hermeneutika dalam studi keislaman, disamping 
diyakini oleh sekelompok pendukung yang menerima hermeneutika dalam studi Keislaman juga pada sisi lain menambah serangkaian diskursus dan perdebatan dikalangan umat Islam. Secara spesifik dari pembahasan yang di ulas sebelumnya dapat di simpulkan:

Pertama, bahwah kehadiran hermeneutika dalam studi keislaman dimulai pada berbagai upaya ulama dan tokoh Islam kontemporer yang mengusung konsep hermeneutika untuk diterapkan pada penafsiran teks Al-qur'an. Beberapa tokoh yang di ulas dalam makalah ini seperti Nasir Hamid, Arkoun, Abu Hasan Hanafi adalah diantara tokoh yang dapat dikatakan mendukung hermeneutika untuk diterima sebagai metode dalam penafsiran Al-qur'an. Dalam asumsi kelompok pendukung bahwah rangkaian sejarah penafsiran teks alqur'an seperti lahirnya sebuah kitab yang menyusun asbab an-nuzul, adalah sebuah bukti bahwah sejak dahulu hermeneutika secara praktis sudah digunakan.

Kedua, menyoroti beberapa kritik terhadap hermeneutika, seperti beberapa upaya yang di lakukan tokoh-tokoh Islam dan pemikirannya yang mengarah pada kritik terhadap hermeneutika seperti Adian Husaini yang meragukan hermeneutika sebagai produksi budaya keilmuan barat yang sulit menemukan titik keserasihan karna dengan tradisi keilmuan Islam, Muhammad Imarah dengan mematahkan asumsi al-qur'an sebagai produk budaya hingga konsep dan kritik Khaled Abu Khaled yang diyakini menampilkan sebuah penyegaran konsep yang lebih kompromis. Sehingga dalam merespon perdebatan ini, penulis menemukan dan memposisikan hermeneutika sebagai suatu ilmu yang dapat dipertimbangkan dalam kajian keislaman, meskipun membutuhkan internalisasi menyeluruh terkait beberapa aspek krusial dalam praktik dan metodologinya terhadap teks Al-qur'an. 


\section{DAFTAR PUSTAKA}

Novianti, Evi. 2008. Tindak Tutur Direktif dalam Bahasa Melayu Sambas. Disertasi Program Pascasarjana, Universitas Diponogoro Semarang.

Ahmad Hifni. Hermeneutika Muderat; Studi Teori Ta'wil Abd alQahir al-Jurjani dan Hermeneutika Paul Ricoeur. Tesis Magister Agama UIN Syarif Hidayutullah, (2018)

Adian Husaini. 2005.Wajah Peradaban Barat. Jakarta: Gema Insani.

Adian Husaini. 2005.Kerukunan Beragama dan Kontroversial

Penggunaan Kata Allah Dalam Agama Kristen. Jakarta: Gema Insani. Argo Victoria. Kontroversi Hermeneutika Sebagai Manhaj Tafsir. Jurnal Hukum Khaira Ummah Vol. 12. No. 1, (2017)

Fadhli Lukman. Hermeneutika Pembebasan Hasan Hanafi dan Relevansinya Terhadap Indonesia.https://www.researchgate.net/publication/3295381 60_hermeneutika_pembebasan (Diakses tanggal 3 Mei 2020 Pukul 07.00 WIB).

Ishak Hariyanto. Hermeneutika Muhammad Arkoun. Jurnal Ilmu alQuran dan Tafsir, Volume 1 No.2, (2018)

Luqmanul Hakim Habibie. Hermeneutik Dalam Kajian Islam. Jurnal Fikri Volume 1 No.1, (2016)

Luluk Khumaerah. Hermeneutika Tradisional Sayyed Hossein Nasr

Dalam The Study Quran A New Translation And Commentary. Skripsi Program Ilmu Al-qur'an dan Tafsir IAIN Salatiga, (2019)

Mudhofir Abdulah. Kesejarahan Al-qur'an dan Hermeneutika. Journal of Qur'an and Haditsh Studies, Vol. 3, No. 1, (2014)

Muhammad Asror dan Syamsul Arifin. Pendekatan Hemeneutika Dalam Studi Islam. https://psmpi2016a.files.wordpress.com/ (diakses pada tanggal 2 mei $2020 \mathrm{Pkl}$ 17.00 WIB).

Muhammad Zamri. Studi Kritis Atas Kritik Muhammad Imarah Terhadap Hermeneutika Nasir Hamid. Tesis Magister Agama UIN Syarif Hidayatullah, (2017).

Muhammad Imarah. 1999. Islam dan Pluralitas; Perbedaan dan Kemajemukan Dalam Bingkai Persatuan. Jakarta, Gema Insani.

Nurkhalis. Diskursus Hermeneutika Dalam Paradigma Keislaman dan Kemoderenan. Jurnal Substantia Volume 17 No.1 (2015) 
Safrudin Edi Wibowo. Kontreversi Penerapan Hermeneutika dalam studi Al-qur'an di Indonesia. Disertasi Bidang Ilmu Agama Islam UIN Yogyakarta, (2017)

Ulya. Hermeneutika Double Movementh; Menuju Penetapan Hukum Bervisi Etis. https://www.researchgate.net/publication/291085863_herme neutika_double_movement_fazlur_rahman_menuju_penetap an_hukum_bervisi_etis. (Diakses pada tanggal 4 Mei 2020 Pkl. 15.00 WIB).

Wahidatul Wafa. Masuknya Hermeneutika dalam Lingkup Ilmu Tafsir. Jurnal al-Tsaqafa Volume 14, No. 01 (2017) 